\title{
PENGARUH LUAS LAHAN, TENAGA KERJA DAN IRIGASI TERHADAP PRODUKSI PADI DI PROVINSI ACEH
}

\author{
${ }^{* a}$ manda fitri ${ }^{* b}$ Murtala \\ *Fakultas Ekonomi dan Bisnis Universitas Malikussaleh \\ a Corresponding author: tala.murtala.gmail.com \\ b mandafitri12@gmail.com
}

A R T I C L E I N F O R M A T I O NA B S T RA C T

\section{Keywords:}

land area, labor, irrigation area, rice production
This study aims to analyze the effect of land area, labor and irrigation area on rice production in Aceh province 1998-2017. This research model uses multiple linear regression. Theresults of the study partially land area (X1) affects Rice Production in Aceh, Labor (X2) affects Rice Productionin Aceh Province, Irrigation (X3). Simultaneously the area of land, labor and irrigation area affect rice production in Aceh Province.

\section{PENDAHULUAN}

Aceh merupakan salah satu provinsi yang ada di Indonesia yang memiliki faktor produksi dan sumber daya alam yang berbeda-beda di setiap daerahnya. Sumber daya alam yang berlimpah tersebut menjadikan provinsi Aceh maju akan industri terutama pertanian. Dengan memiliki tanah yang subur dan didukung iklim yang tropis, menjadikan provinsi Aceh kaya akan hasil pertaniannya terutama komoditi padi. Padi yang di produksi di Aceh sangat baik, ini merupakan penunjang untuk dapat memancing pertumbuhan ekonomi di Aceh. Produksi padi yang baik tidak lepas dari luas lahan dan area irigasi yang mendukung. Semakin luas lahannya semakin banyak pula padi yang dipanen, begitu pula dengan area irigasi, semakin baik dikelola area irigasinya semakin bagus pula hasil produksi padi yang diperoleh para petani.

Silamat (2014) dalam Arimbawa dan Widanta (2017), Peningktan produksipadi dapat dilakukan dengan intensifikasi pertanian dan kegiatan budidaya yang penting dalam intensifikasi pertanian adalah pengolahan tanah atau luas lahan. Faktor produksi tanah terdiri dari beberapa faktor alam lainnya, seperti air, udara, temperature, sinar matahari, dan lainnya. Keberadaan factor produksi tanah, tidak hanya dilihat dari segi luas sempitmya saja, tetapi juga dari segi lainnya. Seperti jenistanah, macam penggunaanlahan (tanahsawah, tegalan, dst), tofografi serta nilai tanah itu sendiri.

Masru'ah dan Soejoto (2013) menjelaskan bahwa tenaga kerja yaitu orang yang mampu menghasilkan produk untuk memenuhi kebutuhan hidupnya. Salahsatu faktor yang punya peranan penting dalam pertumbuhan output adalah tenaga kerja. Hal ini berarti semakin produktif tenaga kerja semakin baik pula produksi barang dan jasa yang dihasilkan, dengan kata lain untuk menunjang produktifitas tenaga kerja terutama di Aceh, Pemerintah dapat melakukan berbagai kebijakan seperti memberikan pelatihan-pelatihan, bimbingan, serta keterampilan yang nantinya akan berdampak positif.

Keterserdiaan, efektivitas dan efisiensi infarstruktur jaringan irigasi yang memadai adalah sangat dibutuhkan. Hal tersebut dikarenakan keberadaan air di negara kita sangat khas, melimpah pada pada bulan-bulan basah karena curah hujan yang tinggi dan kekurangan pada bulan-kering. (Direktorat Pengelolaan Air. 2014). Lebih lanjut dikemukakan dengan adanya jaringan irigasi, air yang melimpah pada bulan-bulan basah dapat ditampung, sehingga bisa mencegah banjir, selain .Selain untuk mencegah terjadinya banjir, adanya jaringan irigasi juga dapat membantu petani terutama di saat kekeringan. 
Produksi padi pada musim tanam kedua pertengahan tahun 2019 di Provinsi Aceh mengalami penurunan. Penurunan produksi disebabkan oleh musim kemarau yang memberikan dampak pada kekeringan areal persawahan sehingga menyebabkan pertumbuhan padi terganggu dan mengakibatkan penurunan hasil produksi. Beberapa daerah yang mengalami kekeringan diantaranya Kabupaten Pidie, Kabupaten Aceh Barat, dan Kabupaten Aceh Barat daya. Kurangnya saluran irigasi menyebabkan kendala dalam penyediaan air sawah (Abdullah, 2019).

Adapun data Produksi Padi, Luas Lahan, Tenaga Kerjadan Areal Irigasi adalah sebagai berikut :

Tabel 1.1

Data Produksi Padi, Laas Lahan, Tenaga Keria dan Areal Irigasi Di Provinsi Aceh

\begin{tabular}{|c|c|c|c|c|}
\hline Tahum & $\begin{array}{c}\text { Produksi Padi } \\
\text { (Ton) }\end{array}$ & $\begin{array}{c}\text { Luas Lahan } \\
\text { (Ha) }\end{array}$ & $\begin{array}{c}\text { Tenaga Kerja } \\
\text { (Jiwa) }\end{array}$ & $\begin{array}{c}\text { Areal Irigasi } \\
\text { (Ha) }\end{array}$ \\
\hline 2013 & 1.956 .939 & 419.183 & 40.764 .720 & 141.490 \\
\hline 2014 & 1.820 .062 & 376.137 & 40.833 .052 & 195.455 \\
\hline 2015 & 2.146 .644 & 461.060 & 40.122 .816 & 194.322 \\
\hline 2016 & $\mathbf{2 . 2 0 4 . 9 9 2}$ & $\mathbf{4 2 9 . 4 8 5}$ & 38.291 .111 & $\mathbf{5 8 . 8 1 5}$ \\
\hline $\mathbf{2 0 1 7}$ & $\mathbf{2 . 5 0 0 . 0 0 0}$ & $\mathbf{5 2 2 . 4 1 6}$ & 39.678 .453 & 11.752 \\
\hline
\end{tabular}

Sumber : Badan Pusat Statistik Indonesia Dan Kementrian Pertanian Taluan 2017

Berdasarkan Tabel di atas pada tahun 2016 luas lahan panen padi menurun dari tahun sebelumnya menjadi 429.485 hektar, disusul dengan tenaga kerja yang ikut menurun juga dari menjadi 38.291.111 jiwa, di tambah luas irigasi yang belum memadai dan ikut menurun juga menjadi 58.815 hektar yang memicu beberapa lahan sawah rusak, akan tetapi pada tahun ini produksi padi justru meningkat dari tahun sebelumnya menjadi 2.204 .992 ton. Begitu juga pada tahun 2017, luas lahan padi meningkat drastis menjadi 522.416 hektar, tenagakerja juga meningkat menjadi 39.678.453 jiwa, namun areal irigasi terus menurun menjadi 11.752 hektar, sedangkan produksi padi meningkat drastis menjadi 2.500.000 ton. Ketika luas lahan meningkat, dan tenaga kerja meningkat seharusnya luas areal irigasi juga harus meningkat menjkadi lebih memadai, agar sesuai air yang dibutuhkan dengan lahan, dan hal ini juga diikuti dengan produksi padi juga ikut meningkat, namun fenomena di atas tidak sesuai dengan teori sebenarnya.

Fenomena-fenomena di atas seperti areal irigasi yang menurun karena dipicu oleh bendungan irigasi yang rusak, dialihfungsikan areal irigasi tersebut untuk bangunan-bangunan yang seharusnya untuk areal irigasi. Nah, permasalahan inilah yang menyebabkan seharusnya ketika areal irigasi menurun luas lahan juga ikut menurun, dan produksi padi menurun, bukan justru meningkat drastis. Dari uraian permasalahan di atas, penulis tertarik untuk melakukan penelitian seberapa besar signifikan pengaruhnya antara luas lahan panen padi, tenagakerja dan luasareal irigasi sawah terhadap produksi padi di provinsiAceh.

Selanjutnya beberapa kajian terdahulu yang pernah meneliti hal yang hampir serupa terdiri dari (Fitri, dkk 2015), (Jamalludin 2016), (Muzdhalifah 2014), dan (Damayanti 2013) yang mana hampir keseluruhan meneliti tentang produksi padi.

Penelitian ini akan mengkaji tetang tinjauan teoritis, selajutnya dibagian ketiga dibahas metode penelitian, pada bagian keempat akan dibahas hasil dan penelitian, dan terakhir bagian kelima akan dibahas tentang simpulan dan saran.

\section{TINJAUAN TEORITIS}

\section{Produksi Padi}

Sinaga (2016) menjelaskan Produksi padi adalah jumlah output atau hasil panen padi dari lahan petani selama satu kali musim tanam. Kemudian produktivitas adalah kemampuan suatu faktor produksi, seperti luas tanah, untuk memperoleh hasil produksi per hektar.

Produksi dan produktivitas disebabkan oleh banyak faktor seperti tanah yg subur, varitasbibit yang ditanam, penggunaanpupuk yang memadai baik jenis maupun takaran, tersedianya air dalam jumlahcukup, teknik bercocok tanamyang tepat dan penggunaan alat-alat produksi pertanian yang memadai dan tersedianya tenaga kerja.

Menurut Muin (2017) Faktor-faktor produksi padi terdiri dari :

1. Tenaga kerja, merupakan faktor produksi yang sangat dominan dalam menghasilkan produksi.

2. Tanah, adalah SDA paling utama, khususnya produksi pertanian. Oleh sebab itu, tanah merupakan salahsatu faktorproduksi yang sangatpenting atau yang mendasar.

3. Benih, adalah biji yang dihasilkan dengan cara dan tujuan khusus untuk disematkan menjadi pertanaman. Kualitas benih itu sendiri akan ditentukan dalam proses perkembangan dan kemasakan benih, panen dan perontokan, pembersihan, pengeringan, penyimpanan benih sampai fase pertumbuhan di persemaian.

4. Pupuk, pemberian vitamin terhadap tanaman, dengan tujuan untuk menjaga daya tahan tanaman, meningkatkan produksi dan mutu 
hasil serta menjaga agar produksi stabil tinggi. Pemberian pupuk diletakkan sekitar 30-40 cm dari batang pokok.

5. Modal, Dalam proses produksi pertanian, modal dibedakan menjadi dua macam, yaitu modal tidak bergerak (biasanya disebut modal tetap) contohnya seperti tanah, bangunan, mesin-mesin.

Muin (2017) mengungkapkan bahwa suatu fungsi produksi menunjukan sifat hubungan diantara faktor-faktor produksi dan tingkat produksi yang dihasilkan. Fungsi produksi dinyatakan dalam bentuk rumus, yaitu :

$\mathbf{Q}=\mathbf{F}(\mathbf{K}, \mathbf{L}, \mathbf{R}, \mathbf{T})$

Dimana :

Q : Jumlahproduksi yang dihasilkan

$\mathrm{K}$ : Jumlahstok modal

L : Jumlah tenagakerja

$\mathrm{R}$ : Kekayaan alam

$\mathrm{T}$ : Teknologi yang digunakan

\section{Luas Lahan}

lahan diartikan sebagai lingkungan fisik yang terdiri atas iklim, relief, tanah, air, flora, fauna serta bentukan hasil budaya manusia. Dalam hal ini lahan yang mengandung pengertian ruang dan tempat. Lahan juga diartikan sebagai lingkungan fisik yang terdiri atas iklim, relief, tanah, air, dan vegetasi serta benda yang ada diatasnya sepanjang ada pengaruhnya terhadap penggunaan lahan termasuk didalamnya juga hasil kegiatan manusia di masa lalu dan sekarang (Sudarti, 2011)

Menurt (Lopang, 2016) Luas Lahan pertanian padi terbagi pada dua bagian diantaranya:

\section{Lahan Sawah}

Tanah sawah adalah tanah pertanian yang berpetak-petak dan dibatasi oleh pematang, saluran untuk menahan/menyalurkan air dan biasanya ditanami padi sawah, tanpa memandang dari mana diperolehnya ataupun status dari tanah tersebut. Yang termasuk pada lahan sawah diantaranya adalah Sawah berpengairan teknis, Sawah Berpengairan Setengah Teknis, dan Sawah Berpengairan sederhana

\section{Lahan Bukan Sawah/Lahan Ladang}

Tanah bukan lahan sawah adalah semua tanah yang tidak termasuk tanah sawah. Tanah yang berstatus tanah sawah yang tidak berfungsi lagi sebagai tanah sawah dimasukan sebagai tanah bukan lahan sawah. Lahan bukan sawah merupakan semua lahan selain sawah yang meliputi : Kebun, Huma, dan Tegal/Kebunan/Ladang/Huma

\section{Tenaga Kerja}

Menurut Badan Pusat Statistik (2019) tenaga kerja adalah setiap orang yang mampu melakukan pekerjaan guna menghasilkan barang dan jasa baik untuk memenuhi kebutuhan sendiri maupun untuk masyarakat. Batas usia kerja yang dianut oleh Indonesia adalah minimum 10 tahun, tanpa batas umur maksimum. Jadi setiap orangatau penduduk yang sudahberusia 10 tahun keatastergolongtenaga kerja.

Suindyah (2011) menyatakan bahwa Sumber daya manusia memiliki 2 pengertian, yaitu:

sumberdaya manusia yang mengandung pengertian usaha kerja, yaitu SDM yang mencerminkan kualitas usaha yang diberikan oleh seseorang dalam waktu tertentu untuk menghasilkan barang dan jasa.

Sumberdaya manusia yang menyangkut manusia yang mampu bekerja untuk mmberikan jasa atau usaha kerja tersebut, pengertian mampu bekerja adalah mampu untuk melakukan kegiatan yang menghasilkan nilai ekonomis berupa barang dan jasa yang dapat dipakai buatmemenuhi kebutuhan masyarakat luas.

Pius (2011) menyebutkan bahwa tenaga kerja dapat dikelompokkan menjadi beberapa jenis berdasarkan kriteria diantaranya yaitu:

1. Berdasarkan Penduduknya terdiri dariTenaga Kerja dan Bukan tenaga kerja.

2. Berdasarkan Batas Kerja terdiri dari Angkatan Kerja dan Bukan Angkatan Kerja.

3. Berdasarkan Kualitasnya, terdiri dari Tenaga Kerja Terdidik, Tenaga Kerja Terlatih, dan Tenaga Kerja Tidak Terdidik \&Tidak Terlatih (Dwiyanto, 2006).

\section{Irigasi}

Purwanto dan Ikhsan (2002) menyebutkan Irigasi adalah kegiatan-kegiatan yang berkaitan dengan usaha untuk mendapatkan air untuk sawah, lading, perkebunan, dan lain-lain usaha pertanian. Usaha tersebut terutama nantinya menyangkut pembuatan sarana dan prasarana untuk membagibagikan air ke sawah-sawah secara teratur dan membuang air kelebihan yang tidak diperlukan lagi untuk keperluan pertanian.

Kebutuhan air irigasi adalah jumlah volume air yang diperlukan untuk memenuhi kebutuhan evaporasi, kehilangan air, kebutuhan air untuk tanaman dengan memperhatikan jumlah air yang diberikan oleh alam melalui hujan dan kontribusi air tanah. Kebutuhan air disesuaikan dengan luas areal 
irigasi yang tersedia dan sesuai dengan kebutuhan dari luas lahan sawah padi yang tersedia. Karena, kekurangan air akan mengakibatkan kegagalan pada hasil produksi karena disebabkan lahan sawah yang kering (Purwanto dan Ikhsan, 2002)

Menurut (Danil, 2004) tujuan dari irigasi antara lain yaitu Membasahi tanaman, Merabuk, Mengatur suhu, Membersihkan tanah atau memberantas hama, dan Kolmatase.

Pemilihan sistem irigasi untuk suatu daerah tergantung dari keadaan topografi, biaya, dan teknologi yang tersedia. Menurut irigasi (Minsyah, 2013) terdapat empat jenis sistem irigasi diantaranya yaitu :

1. Irigasi Gravitasi.

2. Irigasi Siraman.

3. Irigasi Bawah Permukaan.

4. Irigasi Tetesan.

\section{Kerangka Konseptual}

Adapun Kerangka Pemikiran yang dimaksud adalah sebagai berikut :

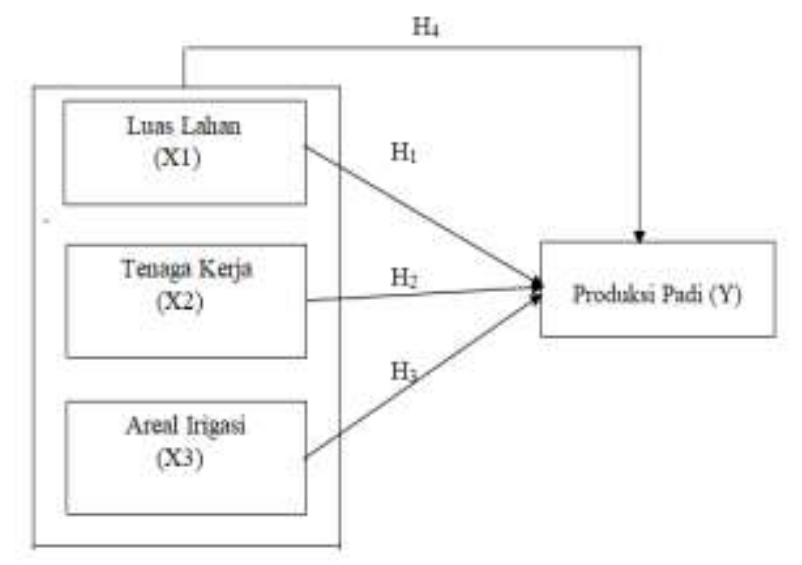

Gambar 2.1

\section{Kerangka Konseptual}

Kerangka konseptual pada gambar di atas menjelaskan bagaimana luas lahan, tenaga kerja, dan areal irigasi memiliki pengaruh terhadap produksi padi, yang artinya semakin bagus kualitas luas lahan, juga tenaga kerja dan areal irigasi maka akan meningkatkan produksi pagi.

\section{Hipotesis}

Hipotesis adalah jawaban sementara terhadap masalah penelitian, yang kebenarannya harus diuji secara empiris. Sesuai topik permasalahan dan tujuan adanya kajian ini, maka hipotesis sebagai berikut:

H1 : Luas Lahan berpengaruh positif dan signifikan terhadapproduksi padidi provinsi Aceh

H2 : Tenaga Kerja berpengaruh positif dan signifikan terhadap produksipadi di provinsiAceh
H3 : Areal Irigasi berpengaruh positif dan signifikan terhadapproduksi padi diprovinsi Aceh

H4 : Luas Lahan, Tenaga Kerja dan Areal Irigasi berpengaruh positif dan signifikanterhadap produksi padidi provinsi Aceh

\section{METODEPENELITIAN}

\section{Objek dan Lokasi Penelitian}

Objek dalampenelitian ini yaitu luas lahan, tenagakerja dan areal irigasi serta produksi padi. Lokasi penelitian inidilakukan di provinsiAceh.

\section{Jenis dan Sumber Data}

Penelitian ini memakai metode Kuantitaif yaitu penelitian yang berupa angka-angka. Data yang digunakan adalah data sekunder yaitu data yang didapat dari Badan Pusat Statistik (BPS), dokumendokumen perusahaan atau organisasi, surat kabar dan majalah, ataupun publikasi lainnya. Mulai dari tahun 1998 sampai 2018.

\section{Teknik Pengumpulan Data}

Teknikyang dipakai dalam pengumpulan data adalah melaluistudi pustaka. Studi pustaka merupakan tehnik untuk mendapatkan informasi melalui catatan,literatur, dokumentasi dan lain-lain yang masih relevan dengan penelitian ini. Data yang digunakan dalam penelitian ini adalah data sekunder yang diperoleh dalam bentuk sudah jadi dari Badan pusat statistik Nasional. Kemudian data yang berhasil penulis himpun dan dijadikan sebagai landasan penelitian.

\section{Definisi Operasionalisasi Variabel}

Dalam penelitian ini menggunakan tiga variabel independen dan satu variabel dependen. Adapun penjelasan untuk masing masing variabel di jelaskan sebagai berikut :

1. Produksi Padi hasil adalah hasil padi yang diperoleh pada saat selama satu kali musim pada jangka waktu tertentu. Variabel ini diukur dengan jumlah produksi padi di provinsi Aceh dengan satuan ton per tahun.

2. Luas Lahan adalah salah satu faktor produksi untuk menghasilkan output dari hasil kegiatan produksi yang efisien dan efektif sesuai input dan hasil yang diharapkan. Variabel ini diukur dengan jumlah luas panen padi sawah dengan satuan dalam hektar.

3. Tenaga Kerja adalah faktor produksiyang tidak dapatdipisahkan denganhasil kegiatan produksi. Variabel ini diukur dengan jumlah penduduk 15 tahun ke atas yang bekerja menurut lapangan 
pekerjaan utama pertanian, perkebunan, kehutanan, perburuan dan perikanan provinsi Aceh dengan satuan jiwa pertahun.

4. Irigasi adalah tempat penampungan air yang dialirkan kedaerah sawah sewaktu-waktu saat diperlukan, sesuai dengan kebutuhan yang dibutuhkan oleh areal lahan sawah. Variabel ini diukur dengan dengan luas areal irigasi yang dikelola secara teknis di provinsi Aceh dengan satuan dalam hektar.

\section{Uji Asumsi Klasik}

\section{Uji Normalitas}

Sugiyono (2012) menyakan bahwa salah satu syarat asumsi dalam analisis statistika adalah data berdistribusi normal. Dalam analisis multivariat, para peneliti menggunakan pedoman kalau tiap variabel terdiri atas 30 data, maka data sudah berdistribusi normal. Untuk menguji dengan lebih akurat, diperlukan alat anlisis dan Eviews menggunakan dua cara, yaitu dengan histogram dan uji Jarque-Bera. Jarque-Bera adalah uji statistik untuk mengetahui apakah data berdistribusi normal, dengan ketentuan :

1) Bila nilai J-B tidak signifikan (lebih kecil dari 2), maka data berdistribusi normal.

2) Bila probabilitasnya lebih besar dari $5 \%$ (bila menggunaan tingkat signifikansi tersebut), maka data berdistribusi normal.

\section{Uji Autokorelasi}

Ghozali (2009) menjelaskan bahwa uji autokorelasi bertujuan menguji apakah dalam model regresi linier ada hubungan antara kesalahan penganggu pada periode $\mathrm{t}$ dengan periode t-1 (sebelumnya). Untuk mendeteksi tersebut dengan cara membandingkan nilai probability obs* R-squared dan alpha $(0,05)$ berikut ketentuan metode pegujian dengan uji autokorelasi :

1) Jika nilai probability obs* R-squared $>$ alpha $(0,05)$, maka berarti tidak terjadi autokorelasi

2) Jika nilai probability obs* R-squared < alpha $(0,05)$, maka berarti terjadi autokorelasi

\section{Uji Multikolinieritas}

Ghozali (2009) multikolinearits adalah lebih dari satu hubungan linear yang sempurna. Dalam sebuah regresi berganda tidak boleh terjadi Uji Multikolinieritas apabila koliniear sempurna maka rergresi dari varibel bebas tiadak dapat di tetntukan. Pendeteksiannya di lakukan dengan menggunakan tolerennce. Pendeteksinyya dengan menggunakan tolerence vallue dan VIF (variianceinflation faktor) Jika nilai tolerence $>0.10$ dan VIF $<10$ maka tidak terdapat multikolinearitas.

\section{Uji Heteroskedastisitas}

Ghozali (2009) bertujuan untukmenguji apakah dalam model regresi terjadi ketidaksamaan variandari residual satu pengamatan ke pengamatan yang lain. Apabila varian residual satu pengamatan ke pengamatan yanglain tetap maka disebut homoskedasitas, dan apabila nilai variannya berbeda maka disebut heteroskedastisitas. Ada beberapa ketentuan yaitu:

Membandingkan $\mathrm{X} 2_{\text {hitung }}$ dengan $\mathrm{X} 2_{\text {tabel, }}$ apabiala X2 hitung $>\mathrm{X} 2$ tabel maka terjadi heteroskedastisitas, dan juga sebaliknya. Kemudian Jika probabilitas Chi- Square $>\alpha$ berarti Ho ditolak dan jika probChi Square $<\alpha$ berarti Ho diterima.

\section{Metode Analisis Data}

Metode analisis data yang yaitu Analisis RegresiLinear Berganda. Model regresi digunakan untuk mengasumsikan bahwa terdapat hubungan linier antara variabel bebas terhap variabel terikat. Adapun persamaannya model dapat ditulis :

$$
\mathrm{Yt}=\alpha+\beta 1 \mathrm{X} 1+\beta 2 \mathrm{X} 2+\beta 3 \mathrm{X} 3+\varepsilon
$$

Keterangan :

$\begin{array}{ll}\mathrm{Y} & =\text { Produksi Padi } \\ \mathrm{X} 1 & =\text { Luas Lahan } \\ \mathrm{X} 2 & =\text { Tenaga Kerja } \\ \mathrm{X} 3 & =\text { Areal Irigasi } \\ \alpha & =\text { Konstanta } \\ \beta & =\text { Koefisien } \\ \varepsilon & =\text { Standar error }\end{array}$

\section{Koefesien Korelasi dan Determinasi}

Sugiyono (2009) mengenai analisis korelasi yaitu suatu carauntuk mengetahui kuatatau tidaknya hubungan antara $\mathrm{x}$ dan $\mathrm{y}$. Koefisienkorelasi dapat dinyatakan dengan rumus sebagai berikut:

$$
r=\frac{n\left(\sum x y\right)-\left(\sum x\right)\left(\sum y\right)}{\left.\left.\sqrt{\left\{n \left(\sum x^{2}\right.\right.}\right)-\left(\sum x\right)^{2}\right\}\left\{n\left(\sum y^{2}\right)-\left(\sum y\right)^{2}\right\}}
$$

keterangan:

$\mathrm{n} \quad=$ jumlah data

$\mathrm{r} \quad=$ koefisien korelasi

Untuk dapat memberi interprestasi seberapa kuat hubungan itu, maka dapat digunakan pedoman seperti yang tertera pada tabel berikut : Dengan VariabelTerikat 


\begin{tabular}{|c|c|}
\hline Nilai korelasi & Interprestasi \\
\hline $0,000-0,199$ & Sangat rendah \\
\hline $0,200-0,399$ & Rendah \\
\hline $0,400-0,599$ & Sedang \\
\hline $0,600-0,799$ & Kuat \\
\hline $0,800-1,000$ & Sangat Kuat \\
\hline
\end{tabular}

Sumber: (Sugiyono: 2009)

Sugiyono (2009) koefisien determinasi yaitu suatu ukuran yang menunjukkan besar ragam naik turunnya variabel terikat yang diterangkan oleh pengaruh linier variabel bebas.Hasil dari analisis ini dinyatakan dalam presentasi batasbatas determinasi sebagai berikut : $0<\mathrm{R}^{2}<1$ Untuk mengetahui nilai koefisien determinasi, maka dapat dihitung dengan cara mengkuadratkan nilai koefisien korelasi $\left(\mathrm{R}^{2}\right)$.

\section{Pengujian Hipotesis}

\section{Uji Parsial (uji t)}

Uji ini dilakukan berdasarkan perbandingan nilai $t_{\text {hitung }}$ masing-masing koefisien regresi dengan nilai $t_{\text {tabel }}$ (nilai kritis) dengan tingkat signifikan 5\% dengan derajat kebebasan df $=(n-$ $\mathrm{k})$, dimana $\mathrm{n}$ adalah jumlah observasi dan $\mathrm{k}$ adalah jumlah variabel.

1. Jika $t_{\text {hitung }}<\mathrm{t}_{\text {tabel }}(\mathrm{n}-\mathrm{k})$, artinya secara individu variabel independen tidak terdapat pengaruh terhadap variabel dependent.

2. Apablla $t_{\text {hittung }}>t_{\text {taabel }}(n-k)$, maka secara parsiial variabel independent berpengaruh terhadap variabel dependen

\section{Uji Simultan (uji f)}

Digunakan untuk menguji pengaruh dari seluruh variabel independent secara simultan atau serentak tehadap variabel dependent. Untuk menentukan nilai $\mathrm{F}_{\text {tabel }}$, tingkat signifikansii yang dipakaisebesar $5 \%$ dengan nilai degree of freedomatau $\mathrm{df}=(\mathrm{n}-\mathrm{k})$ serta $(\mathrm{k}-\mathrm{I})$ dimana $\mathrm{n}$ adalah jumlah observasi, kriteria ujnya yaitu:

1. Jika $F_{\text {hitung }}<F_{\text {tabel }}(\mathrm{k}-1, \mathrm{n}-\mathrm{k})$, maka secara simultan variabel bebas tidak memiiliki pengaruh terhadap variabel teriakat.

2. Jika $F_{\text {hitung }}>F_{\text {tabel }}(\mathrm{k}-1, \mathrm{n}-\mathrm{k})$, maka secara simultan variabel independent berpengaruh terhadap variabel dependent

\section{Hasil Penelitian dan Pembahasan}

Hasil UjiAsumsi Klasik

\section{Hasil Uji Normaliitas}

Berikut adalah hasi ujinormalitas yang diperoleh yaitu :

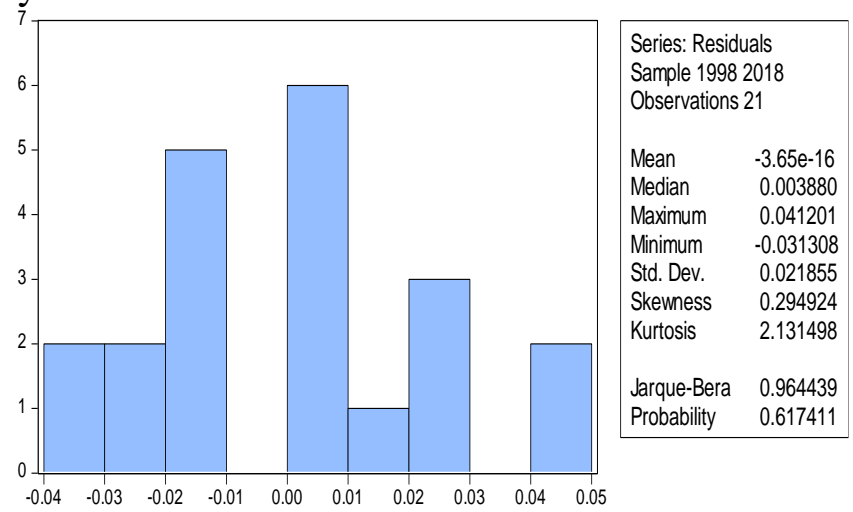

Sumber : HasilEviews, data diolah (2019)

Gambar 4.1 Hasil Uji Normalitas

Dari gambar diatas dapat dilihat nilai residual penelitian berdistribusi normal dimana nilai JarqueBera lebiih keciil dari 2. Pengujia ini jugadapat dibuktikan Jika nilai probabilitas signifikansinya di atas 0,05 maka berarti nilai residual berdistribusi normal. Hasil paenelitian ini menunjukkanbahwa probabilitassebesar 0,617 lebih besar dari 0,05, sehingga di simpulkan bahwa dataterdistribusi normal.

\section{Hasil Uji Autokolerasi}

Hasil yang diperoleh dalam penelitian ini yaitu :

\begin{tabular}{|c|c|c|c|}
\hline \multicolumn{4}{|c|}{$\begin{array}{l}\text { Tabel 4.1 } \\
\text { Hasil Uji Autokorelasi } \\
\text { Breusch-Godfrey Serial Correlation LM Test: }\end{array}$} \\
\hline F-statistic & 0.368842 & Prob. $F(2,15)$ & 0.6976 \\
\hline Obs*R-squated & 0.984349 & Prob. Chi-Square(2) & 0.6113 \\
\hline
\end{tabular}

Sumber : Hasil penelitim, (2019)

Berdasarkan tabeldiatas menunjukkan bahwa tidak terjadi autokorelasi dalam penelitian, karena probability obs* R-squared > alpha $(0,05)$ yaitu $0,611>0,05$. Hasil penelitian ini sejalan dengan teori yang dikemukan Ghozali (2012), yaitu Jika nilai probability obs $*$ R-squared $>$ alpha $(0,05)$, maka berarti tidak terjadi autokorelasi.

\section{Uji Multikolinieritas}

Hasil uji dapat dilihat pada Tabel dibawahini:

Tabel 4.2

Hasil Uji Multikolinieritas

\begin{tabular}{llll}
\hline Variable & $\begin{array}{l}\text { Coefficient } \\
\text { Variance }\end{array}$ & $\begin{array}{l}\text { Uncentered } \\
\text { VIF }\end{array}$ & $\begin{array}{l}\text { Centered } \\
\text { VIF }\end{array}$ \\
\hline C & 8.041303 & 300518.1 & NA \\
Log(Luas_Lahan) & 0.003169 & 19500.64 & 2.271107 \\
Log(Tenaga Keria) & 0.036041 & 411221.4 & 1.832330 \\
Log(Area_trigasi) & 0.000129 & 637.5238 & 1.792423 \\
\hline
\end{tabular}

Sumber : Hasil penelitian, 2019. 
Berdasarkan Tabeldiatas dapatdisimpulkan tidak terjadi multikolinieritas dalam penelitian dimana nilai(VIF) berada di bawah 10 atau tidak lebih dari 10.

\section{Hasil Uji Heteroskedastisitas}

Hasil uji heteroskedastisitas yaiitu :

\begin{tabular}{llll}
\multicolumn{4}{c}{ Tabel 4.3 } \\
Hasil Uji Heteroskedastisitas \\
Heteroskedasticity Test: White \\
\hline F-statistic & 2.781893 & & \\
Obs'R-squared & 11.42076 & Prob. F(6,14) & 0.0538 \\
Scaled explained SS & 4.234263 & Prob. Chi-Square(6) & 0.0762 \\
\hline
\end{tabular}

Sumber : Hasil penelitim, (2019).

Berdasarkan Tabel 4.3 menunjukkan bahwa tidak terjadi heteroskedastisitas dimana nilai $\mathrm{X} 2_{\text {hitung }}<\mathrm{X} 2_{\text {tabel }}$ yaitu $11,42<31,41$. Selnjutnya probabilitas lebihbesar dari 0,05 yaitu 0,07.

\section{Estimsi Regresi Linier Berganda}

Hasil pengujian dalam pnelitian ini yaitu :

Tabel 4.4

Hasil Analisis Regresi Linier Berganda

\begin{tabular}{lrrrrr}
\hline \hline Variable & Coefficient & Std. Error & t-Statistic & Prob. \\
\hline \hline C & -9.190296 & 2.835719 & -3.240905 & 0.0048 \\
Log(Luas_Lahan) & 1.154646 & 0.056294 & 20.51082 & 0.0000 \\
Log(Tenaga_Kerja) & 0.426836 & 0.189846 & 2.248329 & 0.0381 \\
Log(Area_Ingasi) & 0.105118 & 0.011361 & 9.252884 & 0.0000 \\
\hline \hline R-squared & 0.980709 & Durbin-Watson stat & \multirow{2}{*}{1.450804} \\
Adjusted R-squared & 0.977304 & & & \\
F-statistic & 288.0744 & & & \\
Prob(F-statistic) & 0.000000 & & & \\
\hline \hline
\end{tabular}

Sumber : Hasil penelitian, data diolah (2019)

Dari tabel 4.4 maka modelregresi linier bergandaadalah :

$$
\begin{aligned}
\log Y= & -9,190296+1,154646 \log X_{1}+ \\
& 0,426836 \log X_{2}+0,105118 \log X_{3}+e
\end{aligned}
$$

Dari hasil di atas dapat di interpretasi hasil analisis regresi linier berganda yaitu :

Konstanta mempunyai nilai $-9,190296$, menunjukkan apabila variabel luas laahan, jumlah tenaga kerja dan area irigasi memiliki nilai nol maka produksi padi akan berkurang sebesar 9,190296\%.

Koefisien variabel Luas Lahan (X1) mempunyai nilai sebesar 1,154646, Hal ini menunjukkan hubungan yang positif. Artinya apabila luas lahan meningkat $1 \%$ maka produksi padi juga akan meningkat sebesar $1,154646 \%$.
Koefisien variabel tenaga kerja (X2) mempunyai nilai sebesar 0,426836, Artinya apabila tenaga kerja meningkat 1 orang maka produksi padi juga akan meningkat sebesar 0,426836\% .

Koefisien variabel area irigasi (X3) mempunyai nilai sebesar 0,105118, Artinya apabila area irigasi meningkat 1 hektar maka produksi padi juga akan meningkat sebesar $0,105118 \%$.

\section{Hasil Koefisien Korelasi}

Hasil Korelasi $(\mathrm{R})$ dapat diperoleh dari $\mathrm{R}=$ $\sqrt{ }\left(R^{\wedge} 2\right)=\sqrt{ } 0,9773=0,9885$. Jadi hubungan antara luaslahan, tenagakerja dan area irigasi terhadap produksipadi berhubungan sangat kuat secara positif, karena nilai korelasi sebesar 98,85 mendekati $(+1)$.

\section{Hasil Koefisien Determinasi}

Berdasarkan Tabel 4.4 hasil uiji Koefisien determinasi $\left(\mathrm{R}^{2}\right)$ dilihat dari AdjustedR-Square sebesar 0,9773 atau $97,73 \%$. Jadi besarnya pengaruluas lahan, jumlahtenaga kerja danarea irigasi terhadap produksi padi adalah sebesar 97,73 $\%$. Sedangkan sisanya di pengaruhi oleh variabel lain diluar model sebesar 2,27\%.

\section{Hasil Pengujian Hipotesis Hasil Uji Parsial (Uji t)}

Ujiini dilakukandengan membandingkannilai $\mathrm{t}$ hitungdengan $t_{\text {tabel }}$ dengan cara df $(n-k-1)=(21-3$ 1) $=17$ pada $\alpha: 5 \%$ adalah sebesar 1,720 . Berdasarkan hasil pengujian secara parsial pada tabel 4.4 dapatdijelaskan bahwa :

Luas Lahan(X1) berpengaruh terhadapProduksi Padi (Y). Hal ini didasarkan pada nilai $\mathrm{t}$ hitung $>\mathrm{t}$ tabel yakni 20,510 > 1,720 maka terima $\mathrm{H}_{1}$. Hal ini juga bisa dilihat dari probabilitas hitung $<$ p - value atau $0.000<0.05$.

Tenaga Kerja(X2) berpengaruh terhadap Produksi padi (Y). Hal ini didasarkan pada nilai $\mathrm{t}$ hitung > t tabel yakni 2,248>1,720 maka terima $\mathrm{H} 2$. Hal ini juga bisa dilihat dari probabilitas hitung $<\mathrm{p}$ - value atau $0.038<0.05$.

Area Irigasi (X3) berpengaruh terhadap Produksi Padi (Y). Hal ini didasarkan pada nilai $\mathrm{t}$ hitung > t tabel yakni 9,252>1,720 maka terima H3. Hal ini juga bisa dilihat dari probabilitas hitung $<\mathrm{p}$ - value atau $0.000<0.05$. 


\section{Hasil Uji Simultan (Uji f)}

Pengujian secara simultan di gunakan untuk melihat pengaruh secara keseluruhan. Berdasarkan hasil pengujian pada tabel di atas maka dapat dilihat bahwa nilai $F_{\text {hitung }}$ sebesar 288.074 dengan probabilitas sebesar 0,0000, sedangkan ftabel pada $\mathrm{df}=(\mathrm{k}-1)(\mathrm{n}-\mathrm{k})=(3-1)(21$ $3)=(2)(17)$ yaitu sebesar 3,196 dari $\alpha=5 \%$, maka $\mathrm{F}_{\text {hitung }}>\mathrm{F}_{\text {tabel }}$ yaitu $288.074>3,196$. Hal ini juga dapat dilihat dari probabilitas sebesar $0,0000<$ 0,05. Maka dapat disimpulkanH4 diterima artinya secara simultan luas lahan, tenaga kerja dan area irigasi berpengaruh terhadap Produksi padi (Y).

\section{Pembahasan}

\section{Pengaruh Luas Lahan Terhadap Produksi Padi}

Hasil penelitian diperoleh bahwa luas lahan berpengaruh positif dan signifikanterhadap produksi padi di ProvinsiAceh. Hal ini berarti Luas Lahan akan mempengaruhi skala usaha yang pada akhirnya mempengaruhi besar atau kecilnyajumlah produksisuatu usahapertanian. Besar atau kecilnya jumlah produksi suatu usaha pertanian akan mempengaruhi pendapatan petani, yang mana petaniyang mempunyai luas lahan yang luas akanmendapatkan hasil produksi yang banyak sehingga memperoleh penghasilan yang banyak pula, sedangkan petani yang memiliki lualahan yang sedikitmaka produksinya juga sedikitdan akan memperolehpenghasilan yang sedikit pula. Menurut Hernanto (2001) bahwa tanah yang sempit merupakan kelemahan yang cukup besar bagi petani, dengan kata lain usahatani pada lahan yang sempit kurang dapat memberikan keuntungan yang cukup bagi petani dan keluarga untuk hidup layak, sebaliknya semakin tinggi suatu luas lahan, maka kecenderungan untuk menghasilkan produksi semakin tinggi.

\section{Pengaruh Tenaga Kerja Terhadap Produksi Padi}

Hasil penelitian menyatakan bahwa tenaga kerja berpengaruh positif dan signifikan terhadap produksi padi di Provinsi Aceh.

Hal ini artinya tenaga kerja atau SDM yang mampu bekerja untuk mmberikan jasa atau usaha kerja tersebut, pengertian mampu bekerja adalah mampu untuk melakukan kegiatan yang menghasilkan nilai ekonomis yang berupa barang dan jasa yang dapat digunakan untuk memenuhi kebutuhan masyarakat luas. Jadi kesimpulannya, tenaga kerja yang banyak akan menghasilkan hasil produksi besar, apalagi ditambah dengan produktivitas yang tinggi.

\section{Pengaruh Area Irigasi TerhadaProduksi Padi}

Dari hasil penelitian yang telah dilakukan dapat dilihat bahwa area irigasi berpengaruh positif dansignifikanterhadap produksipadi diProvinsi Aceh. Hal ini berarti apabila irigasi merupakan kegiatan-kegiatan untuk memperoleh air ke sawah, ladang, perkebunan dan usaha pertanianlainnya. Usaha tersebut dengan memanfaatkan sarana serta prasarana untuk menunjang pengairan ke sawahsawah dan membuang air yang tidak dibutuhkan sawah. Sehingga apabila bagusnya irigasi maka akan membuat produksi meningkat.

\section{PENUTUP Kesimpulan}

Berdasarkan hasil penelitian dan pembahasan, maka peneliti mengemukakan kesimpulan sebagai berikut :

1. Secara parsial LuasLahan berpengaruh terhadapProduksi Padi di ProvinsiAceh. Lalu variabel TenagaKerja berpengaruh terhadap ProduksiPadi di ProvinsiAceh. Selanjutnyya AreaIrigasi berpengaruh terhadapProduksiPadi di Provinsi Aceh.

2. Secara simultan luas lahan, tenaga kerja dan area irigasi berpengaruh terhadap Produksi padi di Provinsi Aceh.

\section{Saran}

Adapun saran yang dapat diberikan peneliti dalam penelitian ini yaitu :

Bagi pemerintah, diharapkan pemerintah lebih memperhatikan sektor pertanian khususnya sektor tanaman pangan yaitu dengan cara menyediakan area irigasi dan menyediakan pupuk subsidi sehingga masyarakat akanlebih mudah mengelolaserta dapat meningkatkan hasil produksi

Selanjutnya Bagi masyarakat, diharapkan untuk memanfaatkan lahan pertanian secara maksimal sehinggadapat meningkatkanproduksi padi

Bagi penelitiselanjutnya, hasil penelitian ini dapat dijadikan bahan rujukan bagi penelitian yang akan datang.

\section{DAFTAR PUSTAKA}

Arimbawa, Putu Dika dan Widanta, A.A Bagus Putu. 2017. PengaruhLuas Lahan, Teknologi Dan Pelatihan Terhadap PendapatanPetani 
Padi Dengan Produktivitas Sebagai Variabel Intervening Di Kecamatan Mengwi. E-Jurnal Ekonomi Pembangunan Universitas Udayana. Vol 6 No. 8. ISSN : 2303-0178. Hal : 1601-1627.

Badan Pusat Statistik Provinsi Aceh Tahun 2017 Dalam Angka 2018

Damayanti, Lien. 2013. Faktor-Faktor Yang Mempengaruhi Produksi, Pendapatan Dan Kesempatan Kerja Pada Usaha Tani Padi Sawah Di Daerah Irigasi Parigi Moutong. Jurnal SEPA Vol 9 No. 2 Februari 2013. ISSN : 1829-9946. Hal : 249-259.

Daniel, Moehar. 2004. Pengantar Ekonomi Pertanian. Jakarta : PT Bumi Aksara.

Direktorat Jendral Sumberdaya Air, Kementrian Pekerjaan Umum. 2012. Pengelolaan Daerah Aliran Sungai Batanghari. Direktorat Jendral Sumberdaya Air, Kementrian Pekerjaan Jakarta.

Direktorat Pengelolaan Air, Kementrian Pertanian. 2014. Pedoman Teknis Pemeliharaan Jaringan Irigasi. Direktorat Pengelolaan Air, Kementrian Pertanian, Jakarta.

Dwiyanto, Agus, dkk. 2006. Reformasi Birokrasi Publik di Indonesia. Yogyakarta: Gadjah Mada University Press.

Fitri, Nurul, Syechalad, Nur S dan Syahnur, Sofyan.2015. Analisis Faktor-Faktor Yang Mempengaruhi Produksi Padi Di Provinsi Aceh Tahun 2008-2012. Jurnal Ekonomi Universitas Syiah Kuala Volume 3 No.1 Februari 2015. Hal 81-95.

Ghozali, Imam. 2009. Aplikasi Analisis Multivariate dengan program SPSS. Semarang : UNDIP.

Ghozali, Imam. 2012. Aplikasi Analisis Multivariate dengan program SPSS. Semarang : UNDIP

Jamalludin. 2016. Analisis Faktor-Faktor Yang Mempengaruhi Produksi Padi Varietas Unggul Nasional Pada Sawah Tadah Hujan Di Kecamatan Bangkinang Kabupaten Kampar Tahun 2009. Jurnal
Dinamika Pertanian Volume XXXII Nomor 2 Agustus 2016. P ISSN : 0215-2525 dan E ISSN : 2549-7960. Hal : 107-114.

Lopang, Olhviany Beatrix. 2016. Analisis Impor Beras Di Indonesia Tahun 2000-2014. Jurnal Fakultas Ekonomi Dan Bisnis Universitas Hasanuddin.

Masru'ah, D dan Soejoto, A. 2010. Pengaruh Tenaga Kerja dan Investasi Di Sektor Pertanian Terhadap Pertumbuhan Sektor Pertanian (Studi Kasus: Di Provinsi Jawa Timur). Jurnal Ekonomi Universitas Negeri Surabaya. Hal. 1- 18.

Minsyah, Nur Imdah, Meilin, Araz dan Endrizal. 2013. Optimalisasi Pemanfaatan Lahan Sawah Irigasi Untuk Peningkatan Produksi Padi Di Provinsi Jambi Tahun 2007-2011. Jurnal Balai Pengkajian Teknologi Pertanian Jambi. Hal 247-257.

Muin, Muhyina. 2017. Pengaruh Faktor Produksi Terhadap Hasil Produksi Merica Di Desa Era Baru Kecamatan tellulimpoe kabupaten sinjai. Jurnal Economix Volume 5 Nomor 1 Juni 2017. Hal 203-2014.

Muzdhalifah. 2014. Pengaruh Irigasi Terhadap Usahatani Padi Sawah Di Desa Sidera Kecamatan Sigi Biromaru. E-j Agrotekbis Vol 2 No. 1 Februari 2014. ISSN : 2338- 3011. Hal : 76-84.

Pius, Partanto dkk. 2001. Kamus Ilmiah Popular. Surabaya : Arkola

Purwanto dan Ikhsan, J. 2002. Analis Kebutuhan Air Irigasi Pada Daerah Irigasi Bendung Mricani. Jurnal Ilmiah Semesta Teknika Vol. 9. No. 1.206 Hal 83-93.

Rahim, Abd. 2012. Model Ekonometrika Perikanan Tangkap. Makassar : Badan Penerbit UMN.

Salim, Mursalam. 2011. Pengaruh Investasi Dan Tenaga Kerja Terhadap PDRB (Studi Kasus: Provinsi Papua). Jurnal Dosen Fakultas Ekonomi. Universitas Yapis: Papua.

Sinaga, Rolas. 2016. Pengenalan Sarana Produksi Pertanian. Academidu 17 Maret 2016. 
Sudarti. 2011. Analisis Efisiensi Penggunaan Faktor Produksi Pada Usaha Tani Padi Sawah Di Desa Mopuya Utara Kecamatan Dumoga Utara Kabupaten Dolang Mangundo. Jurnal Universitas Sam Ratulangi. Vol 7 No.1 Januari 2011.

Sugiyono. 2012. Metode Penelitian Kuantitatif Kualitatif dan R\&D. Bandung : Alfabeta.

Sulistyono, Eko, Suwarno dan Lubis, Ikandar. 2012. Pengaruh Frekuensi Irigasi Terhadap Pertumbuhan Dan Produksi Lima Galur Padi Sawah. Jurnal AGROVIGOR VOLUME 5 No. 1 Maret 2012. ISSN : 1979-5777 Hal : 1-8. 